\title{
Profil Penggunaan Antibiotik Pada Pasien Pediatri Rujukan Berdasarkan Sistem Defined Daily Dose (DDD)
}

\author{
Nurul Fatmawati Pua Upa', Widyati², dan Frans O.H. Prasetyadi ${ }^{2}$ \\ 'Program Studi Magister Ilmu Farmasi Universitas Surabaya, Surabaya, Indonesia \\ ${ }^{2}$ RSPAL Dr. Ramelan Surabaya, Surabaya, Indonesia \\ Korespondensi: Nurul Fatmawati Pua Upa \\ Email: nurulfatmawatipuaupa@gmail.com
}

Submitted : 20-12-2019, Revised : 30-01-2020, Accepted : 31-05-2020

\begin{abstract}
ABSTRAK: Tujuan dari penelitian ini adalah untuk mengetahui profil penggunaan antibiotik pada pasien pediatri yang dirujuk ke RSPAL Dr. Ramelan selama bulan April hingga Juli 2019. Penelitian ini merupakan penelitian observasional deskriptif yang dilakukan secara prospektif. Variabel yang terlibat adalah besar penggunaan antibiotik yang dinyatakan dalam satuan Defined Daily Dose (DDD)/100 hari rawat inap dan standar yang digunakan berdasarkan ketentuan dari WHO. Terdapat 30 subyek yang dirujuk ke RSPAL Dr. Ramelan. Sebagian besar subyek telah tinggal lebih dari 48 jam di rumah sakit sebelumnya, mereka menerima antibiotik sejak hari pertama di RSPAL Dr. Ramelan. Sebanyak 13 subyek (43\%) menerima antibiotik yang serupa dengan rumah sakit sebelumnya dan 17 subyek lainnya (57\%) tidak. Hasil penelitian menunjukkan bahwa penghitungan total konsumsi antibiotik sebesar 10,50 DDD/100 hari-rawat dari 8 jenis antibiotik yang digunakan yaitu ampisilin-sulbaktam, kloksasilin, seftriakson, amikasin, gentamisin, meropenem, levofloksasin, dan metronidazol. Konsumsi antibiotik tertinggi adalah meropenem yang memiliki 3,49 DDD/100 hari-rawat, konsumsi antibiotik terendah adalah kloksasilin yang memiliki 0,05 DDD/100 hari-rawat. Diharapkan penelitian ini dapat menjadi salah satu indikator evaluasi penggunaan antibiotik yang dilakukan di rumah sakit agar dapat meningkatkan rasionalitas penggunaan antibiotik sehingga menurunkan resiko penyebaran resistensi antibiotik khususnya melalui pasien rujukan.
\end{abstract}

Kata kunci: profil penggunaan antibiotik; pediatri; pasien rujukan; DDD

\begin{abstract}
The purpose of this study was to determine the profile of antibiotic use in pediatric patients referred to Dr. Ramelan Naval Hospital during April to July 2019. This research is a descriptive observational study conducted prospectively. The variable involved is the amount of antibiotic use expressed in units of Defined Daily Dose (DDD)/100 bed days and the standard used based on the provisions of WHO. There were 30 subjects who were referred to Dr. Ramelan Naval Hospital. Most of the subjects had stayed more than 48 hours in the hospital before, they received antibiotics from the first day at Dr. Ramelan Naval Hospital. Thirteen subjects (43\%) received antibiotics similar to the previous hospital and 17 other subjects (57\%) did not. The results showed that the calculation of total antibiotic consumption was 10.50 DDD/100 bed days of 8 types of antibiotics used, namely ampicillin-sulbactam, cloxacillin, ceftriaxone, amikacin, gentamicin, meropenem, levofloxacin, and metronidazole. The highest antibiotic consumption was meropenem which had 3.49 DDD/100 bed days, the lowest antibiotic consumption was cloxacillin which had 0.05 DDD/100 bed days. It is expected that this research can be one of the indicators of evaluating the use of antibiotics carried out in hospitals in order to increase the rationality of antibiotic use so as to reduce the risk of spreading antibiotic resistance especially through referral patients.
\end{abstract}

Keywords: profile of antibiotic use; pediatric; referral patients; DDD 


\section{Pendahuluan}

Paparan infeksi bakteri terhadap pediatri lebih tinggi daripada orang dewasa, karena sistem kekebalan tubuh belum sepenuhnya berkembang dan pediatri cenderung lebih banyak terkena bakteri penyebab penyakit melalui kegiatan sehari-hari, terutama pada kelompok neonatus [1]. Proses farmakokinetik dan farmakodinamik obat terutama antibiotik pada pediatri berbeda dibandingkan dengan orang dewasa karena adanya perubahan fisiologis, misalnya konsentrasi protein plasma yang rendah dan komposisi cairan tubuh yang tinggi pada pediatri dapat mengubah distribusi obat, selain itu proses metabolisme seringkali belum matang saat lahir sehingga dapat menyebabkan penurunan klirens dan waktu paruh yang lama untuk obat-obatan yang metabolismenya merupakan mekanisme signifikan untuk eliminasi [2,3]. Tingginya jumlah pasien pediatri yang dirawat di rumah sakit dan terbatasnya jumlah tenaga kesehatan pada rumah sakit tertentu menjadi salah satu faktor pemindahan pasien ke rumah sakit lain yang lebih lengkap fasilitasnya. Pasien transfer antar rumah sakit atau yang dikenal sebagai pasien rujukan memiliki peluang potensial untuk menjadi jalur transmisi yang penting bagi wabah penyakit termasuk infeksi dan peningkatan patogen seperti methicilin-resistant Staphylococcus aureus (MRSA) atau enterococci yang resisten terhadap vankomisin mengingat pola infeksi pada setiap rumah sakit berbeda $[4,5]$.

Resistensi antibiotik terjadi akibat mutasi pada gen kromosom atau dengan transfer gen horizontal antara mikroorganisme yang berbeda [6]. Penelitian yang dilakukan Hadi dkk. menunjukkan bahwa di Indonesia terjadi peningkatan persentase bakteri resisten seperti extendedspectrum beta-laktamase (ESBL) K. pneumoniae (58\%), E. coli (52\%) dan methicillin-resistant S. aureus (MRSA) (24\%) [7]. Penelitian yang dilakukan oleh Xu Yanling dkk. menunjukkan bahwa urutan tingkat resistensi terhadap imipenem pada genus Enterobacteriaceae selama periode
2000-2012 adalah Serratia spp. (1,8\%), Proteus spp. (1,6\%), Klebsiella spp. (0,8\%), Citrobacter spp. (0,8\%), Enterobacter spp. (0,7\%), dan E. coli $(0,2 \%)$ [8]. Resistensi bakteri terjadi dikarenakan pemilihan antibiotik yang tidak tepat, sehingga menjadi masalah kesehatan yang sewaktu-waktu dapat menyebar dan menyebabkan infeksi baru $[9,10]$. Penelitian yang dilakukan di RSUP Fatmawati Jakarta pada 149 pasien sepsis neonatorum yang menerima antibiotik menunjukkan bahwa terjadi ketidaksesuaian dosis sebesar $20,13 \%$ dan frekuensi pemberian antibiotik sebesar 26,17\% [11].

Besarnya penggunaan antibiotik berkaitan erat dengan kejadian resistensi bakteri terhadap antibiotik yang merupakan masalah kesehatan masyarakat dan menjadi perhatian utama di seluruh dunia, hal ini dapat berdampak pada morbiditas dan mortalitas [12]. Antibiotic stewardship (penataan pelayanan antibiotik) sebagai cara untuk mengoptimalkan penggunaan antibiotik agar dapat mencegah perkembangan resistensi dan memperbaiki outcome pasien melalui pembentukan tim Program Pengendalian Resistensi Antimikroba (PPRA) yang telah diterapkan termasuk di RSPAL (Rumah Sakit Pusat Angkatan Laut) Dr. Ramelan, Surabaya. Salah satu indikator mutu PPRA di rumah sakit adalah melakukan evaluasi penggunaan antibiotik, yang bertujuan memberikan informasi pola penggunaan antibiotik yang dapat dilakukan salah satunya dengan cara audit jumlah penggunaan antibiotik di rumah sakit berdasarkan sistem Defined Daily Dose (DDD) sebagai suatu alat untuk menunjukkan statistik penggunaan obat dengan maksud meningkatkan kegunaan obat $[13,14]$. Berdasarkan pertimbangan tersebut maka dilakukan penelitian untuk melihat bagaimana profil penggunaan antibiotik pada pasien pediatri rujukan dari rumah sakit lain berdasarkan sistem DDD di RSPAL Dr. Ramelan.

\section{Metode}

Penelitian ini merupakan penelitian 
observasional bersifat deskriptif yang dilakukan secara prospektif pada pasien pediatri rujukan yang menerima antibiotik di RSPAL Dr. Ramelan Surabaya periode April sampai dengan Juli 2019. Penelitan ini telah dinyatakan layak etik oleh komisi etik penelitian kesehatan RSPAL Dr. Ramelan Surabaya dengan Nomor: 48/EC/ KERS/2019.

\subsection{Kriteria inklusi dan eksklusi}

Subyek pada penelitian ini adalah pasien pediatri rujukan dari rumah sakit lain yang menerima antibiotik di RSPAL Dr. Ramelan Surabaya periode April - Juli 2019 yang memenuhi kriteria penelitian yaitu kriteria inklusi dan kriteria eksklusi. Kriteria inklusi meliputi: (1) usia 0-14 tahun; (2) merupakan pasien rujukan dari rumah sakit lain; (3) riwayat lama perawatan di rumah sakit sebelumnya minimal 48 jam (2 hari); (4) menerima antibiotik tunggal maupun kombinasi dalam rentang waktu pengambilan data dimulai sejak hari pertama di RSPAL Dr. Ramelan Surabaya. Kriteria eksklusi dalam penelitian ini adalah pasien yang berasal dari keluarga yang menolak untuk diikutsertakan dalam penelitian ini.

\subsection{Teknik pengambilan sampel}

Teknik pengambilan sampel secara nonprobability sampling yaitu consecutive sampling, dimana setiap pasien pediatri rujukan baru yang ditemui masuk RSPAL Dr. Ramelan Surabaya dan sesuai kriteria penelitian diikutsertakan sebagai subyek penelitian.

\subsection{Pengambilan data}

Data yang dibutuhkan dalam penelitian ini adalah catatan penggunaan obat subyek dalam rekam medik dan data DDD antibiotik terkait yang telah diklasifikasikan dalam Anatomical Therapeutic Chemical (ATC) pada ATC/DDD Index 2019 yang telah dibuat oleh WHO dan dapat di akses melalui http://whocc.no/atc_ddd_index/ [14]. Data yang diambil dalam setiap rekam medik pasien meliputi: (1) nama antibiotik; (2) regimen dosis antibiotik; (3) interval pemberian antibiotik; (4) rute pemberian antibiotik; (5) waktu pemberian antibiotik, sedangkan data yang diambil dalam ATC/DDD Index 2019 adalah kode ATC dan nilai DDD antibiotik yang digunakan pasien selama periode penelitian. Data yang diperoleh kemudian diolah menggunakan metode DDD/100 hari rawat.

\subsection{Perhitungan $D D D / 100$ hari rawat inap}

Perhitungan Defined Daily Dose (DDD/100 hari rawat) dilakukan dengan memperhatikan Anatomical Therapeutic Chemical (ATC)/DDD, dan setiap antibiotik memiliki nilai DDD yang berbeda berdasarkan ketentuan dari WHO (berdasarkan rata-rata dan indikasi utama pada orang dewasa) $[14,15]$. Berikut ini adalah cara perhitungan DDD/100 hari rawat inap [15]:

a. Mengumpulkan semua data subyek penelitian di RSPAL Dr. Ramelan yang sesuai dengan kriteria penelitian;

b. Menghitung total lamanya waktu rawat inap (total Length of Stay/LOS) seluruh subyek penelitan;

c. Menghitung jumlah dosis antibiotik (gram) selama subyek dirawat;

d. Menghitung DDD Antibiotik:

$$
D D D=\frac{\text { Jumlah dosis antibiotik selama dirawat }(\text { gram })}{D D D W H \text { antibiotik }(\text { gram })}
$$

e. Menghitung DDD/100 hari rawat:

$$
\frac{D D D}{100} \text { hari rawat }=\frac{\text { Total DDD antibiotik }}{\text { Total LOS }} \times 100
$$

\subsection{Analisis data}

Data yang diperoleh dianalisis secara deskriptif menggunakan bantuan program Excel, kemudian disajikan dalam bentuk tabel dan diagram.

\section{Hasil dan diskusi}

Dari 30 subyek penelitian yang dirujuk ke RSPAL Dr. Ramelan Surabaya dan sesuai kriteria penelitian, terdapat 76 regimen antibiotik yang diresepkan. 


\subsection{Karakteristik subyek}

Karakteristik dari 30 subyek penelitian berdasarkan gender terbanyak adalah subyek laki-laki sebanyak 20 pasien (67\%), sedangkan perempuan sebesar 10 pasien (33\%). Berdasarkan usia, 2 kelompok usia pasien terbanyak berturut-turut adalah kelompok pasien dengan usia $<1$ tahun (neonatus lahir cukup bulan usia 0-28 hari) sebanyak 16 pasien (53\%) dan neonatus prematur sebanyak 11 pasien (37\%). Jumlah pasien terbanyak berdasarkan kelompok lama perawatan di RSPAL Dr. Ramelan adalah pasien dengan lama perawatan selama 15-21 hari yaitu sebanyak 10 pasien (33\%), jumlah pasien terbesar berdasarkan demografi asal rumah sakit rujukan adalah rumah sakit di Kabupaten Sidoarjo sebesar 11 pasien (36\%) dan jumlah pasien terbesar berdasarkan jenis kasus pasien pediatri rujukan adalah kasus bedah saluran cerna sebanyak 17 pasien (57\%). Berdasarkan riwayat penggunaan antibiotik, sebanyak 13 pasien (43\%) menerima antibiotik yang sama dengan rumah sakit sebelumnya dan 17 pasien (57\%) menerima antibiotik yang berbeda dari rumah sakit sebelumnya (Tabel 1 ).

\subsection{Profil penggunaan antibiotik dinyatakan dalam DDD/100 hari rawat}

Berdasarkan hasil perhitungan DDD/100 hari rawat subyek penelitian selama periode AprilJuli 2019 menunjukkan total DDD/100 hari rawat sebesar 10,50 DDD/100 hari rawat. Nilai ini berasal dari 8 jenis antibiotik yang digunakan. Hasil perhitungan yang diperoleh dilakukan dengan cara jumlah dosis antibiotik yang diterima subyek selama dirawat dibagi dengan standar DDD yang ditetapkan WHO berdasarkan jenis antibiotik. Hasil DDD yang diperoleh kemudian dibagi dengan total Length of Stay (LOS) dari 30 subyek yang diamati, lalu dikalikan 100 .

Berdasarkan perhitungan DDD/100 hari rawat subyek, terdapat 3 antibiotik berturut-turut yang memiliki nilai DDD/100 hari rawat terbesar diantaranya adalah antibiotik meropenem
(J01DH02) sebesar 3,49 DDD/100 hari rawat, seftriakson (J01DD04) sebesar 1,97 DDD/100 hari rawat, dan gentamisin (J01GB03) sebesar 1,49 DDD/100 hari rawat (Tabel 2 dan Gambar 1). Hasil perhitungan DDD/100 hari rawat di atas dibandingkan dengan hasil studi konsumsi penggunaan antibiotik berdasarkan DDD/100 hari rawat pada pasien pediatri di RSUD Dr. M. Yunus Bengkulu terdapat perbedaan, yaitu total DDD/100 hari rawat sebesar 50,9 DDD/100 hari rawat, dimana urutan 3 antibiotik dengan nilai DDD/100 hari rawat terbesar diantaranya adalah antibiotik ampisilin (26,00 DDD/100 hari rawat), gentamisin (12,2 DDD/100 hari rawat), dan sefotaksim (5,1 DDD/100 hari rawat) [16]. Adanya perbedaan kasus yang dihadapi, menunjukkan bahwa jenis antibiotik dengan besar konsumsi antara pasien rujukan dan pasien biasa (non rujukan) berbeda, dimana pada pasien pediatri rujukan lebih banyak kasus berat sehingga penggunaan antibiotik cenderung pada antibiotik spektrum tinggi.

Semakin kecil penggunaan antibiotik menunjukkan keselektifan dokter dalam meresepkan antibiotik sehingga lebih mendekati prinsip rasionalitas dalam menggunakan antibiotik [17]. Apabila penggunaan antibiotik yang dinyatakan dalam DDD lebih besar dan tidak sesuai dengan standar yang ditetapkan oleh WHO maka hal tersebut menunjukkan adanya kemungkinan peresepan dan penggunaan antibiotik yang tidak selektif pada pasien, dan hal tersebut akan menimbulkan kekhawatiran besarnya kemungkinan ditemui peresepan dan penggunaan antibiotik yang tidak tepat indikasi yang akan berpengaruh pada kerasionalan dan ketepatan indikasi [18]. Lebih dari dua pertiga studi menemukan hubungan antara besarnya penggunaan antibiotik dengan resistensi antibiotik, ketika penggunaan antibiotik lebih tinggi maka dapat meningkatkan resistensi bakteri terhadap antibiotik, begitupun penurunan penggunaan antibiotik dapat menurunkan tingkat resistensi terhadap antibiotik [19].

Berdasarkan hasil penelitian ini, jenis 
Tabel 1. Karakteristik pasien pediatri rujukan yang menerima antibiotik di RSPAL Dr. Ramelan Surabaya periode April-Juli 2019

\begin{tabular}{|c|c|c|c|c|}
\hline $\begin{array}{l}\text { Karak- } \\
\text { teristik } \\
\text { pasien }\end{array}$ & Keterangan & & Jumlah & $\begin{array}{l}\text { Persentase } \\
\text { (\%) }\end{array}$ \\
\hline \multirow[t]{2}{*}{ Gender } & Laki-laki & & 20 & 67 \\
\hline & Perempuan & & 10 & 33 \\
\hline \multirow[t]{5}{*}{ Usia } & \multirow[t]{2}{*}{$<1$ tahun } & Neonatus prematur & 11 & 37 \\
\hline & & $\begin{array}{l}\text { Neonatus aterm }(0-28 \\
\text { hari) }\end{array}$ & 16 & 53 \\
\hline & \multirow[t]{2}{*}{ 1-4 tahun } & $>28$ hari -23 bulan & 2 & 7 \\
\hline & & 2-11 tahun & 1 & 3 \\
\hline & 5-14 tahun & & 0 & 0 \\
\hline \multirow{4}{*}{$\begin{array}{l}\text { Lama pe- } \\
\text { rawatan di } \\
\text { RSPAL Dr. } \\
\text { Ramelan }\end{array}$} & 1-7 hari & & 9 & 30 \\
\hline & 8-14 hari & & 9 & 30 \\
\hline & 15-21 hari & & 10 & 33 \\
\hline & $>30$ hari & & 2 & 7 \\
\hline \multirow[t]{9}{*}{ Asal RS } & Surabaya & & 6 & 20 \\
\hline & Sidoarjo & & 11 & 36 \\
\hline & Gresik & & 2 & 7 \\
\hline & Gempol, Krian & & 2 & 7 \\
\hline & Madura & & 2 & 7 \\
\hline & Lamongan & & 3 & 10 \\
\hline & Jombang & & 1 & 3 \\
\hline & Mojokerto & & 2 & 7 \\
\hline & Bojonegoro & & 1 & 3 \\
\hline \multirow[t]{5}{*}{ Jenis kasus } & Bedah saluran cerna & & 17 & 57 \\
\hline & Gangguan pernafasan & & 10 & 34 \\
\hline & Gangguan saraf & & 1 & 3 \\
\hline & Gangguan gastrointestinal & & 1 & 3 \\
\hline & Gangguan jantung bawaan & & 1 & 3 \\
\hline \multirow{2}{*}{$\begin{array}{l}\text { Riwayat } \\
\text { penggu- } \\
\text { naan anti- } \\
\text { biotik }\end{array}$} & $\begin{array}{l}\text { Antibiotik sama dengan RS sebelum- } \\
\text { nya }\end{array}$ & & 13 & 43 \\
\hline & $\begin{array}{l}\text { Antibiotik berbeda dari RS sebelum- } \\
\text { nya }\end{array}$ & & 17 & 57 \\
\hline
\end{tabular}

antibiotik yang cenderung lebih banyak diresepkan pada subyek penelitian adalah antibiotik berspektrum luas, dalam hal ini adalah meropenem, berbeda dengan rumah sakit lain dengan jenis antibiotik terbesar yang digunakan cenderung pada ampisilin [16]. Hal ini terjadi dikarenakan meropenem terbanyak digunakan pada subyek neonatus dengan bedah 
Tabel 2. Hasil perhitungan nilai DDD/100 hari rawat untuk penggunaan antibiotik pada pasien pediatri rujukan di RSPAL Dr. Ramelan Surabaya periode April-Juli 2019

\begin{tabular}{lllll}
\hline Kode ATC & Jenis antibiotik & $\sum$ Dosis (gram) & Total DDD Antibiotik & $\begin{array}{l}\text { DDD/100 hari } \\
\text { rawat inap }\end{array}$ \\
\hline J01DH02 & Meropenem & 42,27 & 14,09 & 3,49 \\
J01DD04 & Seftriakson & 15,65 & 7,83 & 1,97 \\
\hline J01GB03 & Gentamisin & 1,42 & 5,92 & 1,49 \\
J01MA12 & Levofloksasin & 2,26 & 4,52 & 1,14 \\
\hline J01CR01 & Ampisilin dan inhib- & 25,28 & 4,21 & 1,06 \\
& itor beta laktamase & & & 0,83 \\
J01GB06 & Amikasin & 3,29 & 3,29 & 0,48 \\
J01XD01 & Metronidazol & 2,83 & 1,89 & 0,05 \\
J01CF02 & Kloksasilin & 0,41 & 0,20 & 10,50 \\
\hline Total & & 93,41 & 41,95 & \\
\hline
\end{tabular}

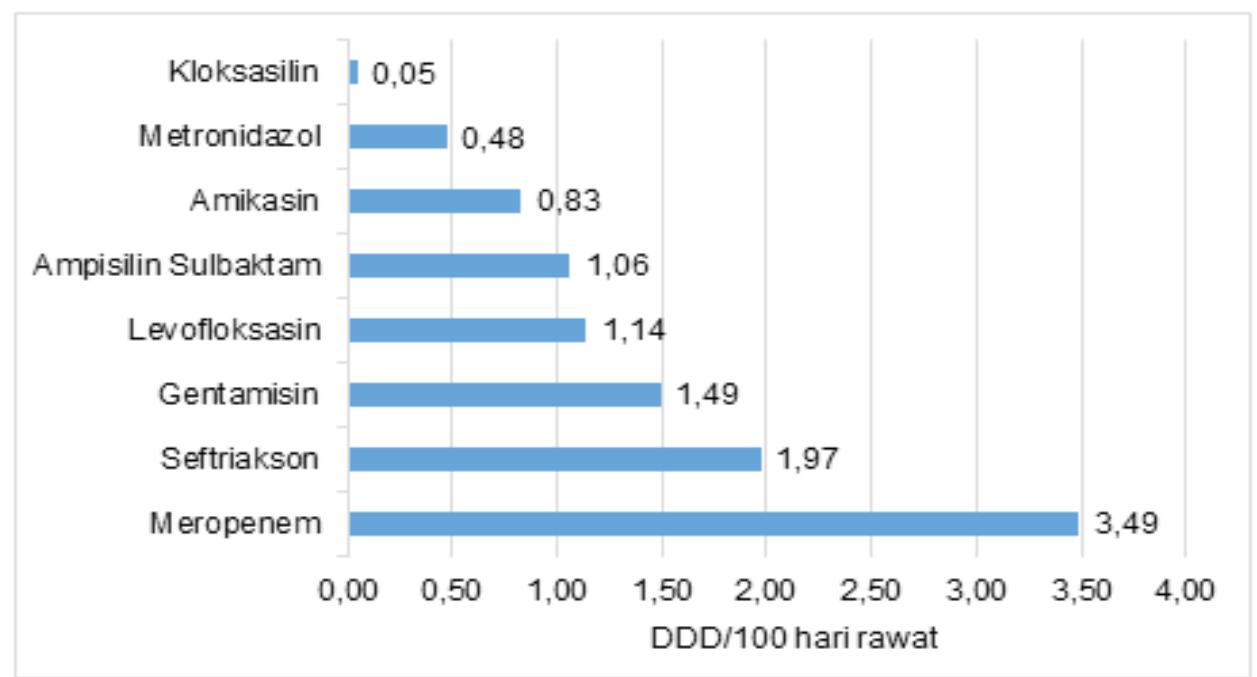

Gambar 1. Diagram besar konsumsi antibiotik pada pasien pediatri rujukan di RSPAL Dr. Ramelan selama periode April-Juli 2019

saluran cerna yang datang disertai kondisi memburuk dan kritis, sehingga ditempatkan dalam ruangan Neonatal Intensive Care Unit (NICU)/Pediatric Intensive Care Unit (PICU). Menurut Naderi dkk., sebagian besar pasien yang sakit kritis memerlukan antibiotik spektrum luas termasuk karbapenem untuk mengatasi risiko infeksi dan perburukan kondisi pasien, mengingat berdasarkan studi systematic review pada neonatus yang menjalani prosedur bedah terutama pada saluran cerna berisiko lebih tinggi mengalami surgical site infections (SSI) yang terjadi paska operasi pada area tempat operasi dilakukan, dengan persentase sebesar $95,4 \%$ [20, 21]. Selain itu, pasien rujukan datang dengan membawa bakteri dari rumah sakit sebelumnya dan telah menggunakan antibiotik pilihan pertama di rumah sakit sebelumnya [4]. Dengan adanya evaluasi penggunaan antibiotik berdasarkan DDD/100 hari rawat diharapkan dapat membantu untuk membandingkan besar penggunaan antibiotik antar jenis pasien, antar 
bangsal, maupun antar rumah sakit tertentu sehingga dapat meningkatkan rasionalitas penggunaan antibiotik, mengingat evaluasi kuantitas penggunaan antibiotik berdasarkan Defined Daily Dose (DDD) termasuk dalam Antimicrobial Stewardship Program (ASP). Suatu kajian sistematis terkait dengan implementasi ASP di kawasan Asia terhadap 28 artikel penelitian, menunjukkan bahwa jenis intervensi ASP yang paling banyak diimplementasikan pada institusi kesehatan di Asia adalah audit peresepan antibiotik yang dilakukan secara prospektif dan disertai dengan pemberian umpan balik (prospective audit with intervention and feedback), implementasi ASP terbukti tidak menyebabkan perburukan luaran klinis pasien dan dapat menurunkan temuan patogen resisten serta menurunkan biaya pengadaan antibiotik dalam suatu institusi kesehatan [22]. Pada kajian sistematis tersebut, belum ditemukan adanya bukti penelitian terpublikasi terkait implementasi ASP di Indonesia, meskipun demikian dengan mempertimbangkan dampak positif tersebut, sangat diharapkan agar ASP dapat diimplementasikan pada institusi kesehatan di Indonesia dengan memperhatikan ketersediaan sumber daya dan konteks budaya lokal [22].

\section{Keterbatasan Penelitian}

Keterbatasan dalam penelitian ini diantaranya adalah Defined Daily Dose (DDD) yang digunakan berdasarkan indikasi pada orang dewasa, sementara menurut WHO, DDD pediatri terutama neonatus sulit untuk ditetapkan sehingga DDD secara umum dapat digunakan pada pediatri sebagai alat pengukuran standar untuk perbandingan keseluruhan. Selain itu, peneliti tidak dapat mengontrol faktor-faktor yang mungkin berpengaruh terhadap hasil penelitian seperti usia pediatri yang cenderung lebih banyak pada kelompok neonatus, kemudian pasien pediatri rujukan yang menerima antibiotik pada hari ke-2 atau pada pertengahan perawatan di RSPAL Dr. Ramelan
Surabaya juga tidak dapat selalu dikontrol.

\section{Kesimpulan}

Hasil penelitian menunjukkan bahwa penggunaan antibiotik terbesar pada pasien pediatri yang dirujuk ke RSPAL Dr. Ramelan Surabaya selama periode April - Juli 2019 adalah antibiotik meropenem sebesar 3,49 DDD/100 hari rawat. Profil penggunaan antibiotik pada pasien pediatri rujukan berdasarkan sistem Defined Daily Dose (DDD) dapat menjadi salah satu indikator evaluasi penggunaan antibiotik yang dilakukan di rumah sakit agar dapat meningkatkan rasionalitas penggunaan antibiotik sehingga menurunkan resiko penyebaran resistensi antibiotik melalui pasien rujukan. Perlu dilakukan evaluasi antibiotik secara komprehensif terhadap pasien rujukan baik dari sisi kualitas antibiotik, perbaikan outcome terapi, dan pengecekan kultur bakteri secara berkala.

\section{Ucapan Terima Kasih}

Peneliti menyampaikan ucapan terimakasih kepada RSPAL Dr. Ramelan Surabaya yang telah memberikan izin untuk dapat melakukan pengambilan data penelitian.

\section{Daftar Pustaka}

1. Buccellato E, Melis M, Biagi C, Donati M, Motola D, Vaccheri A. Use of Antibiotics in Pediatrics: 8-Years Survey in Italian Hospitals. PLoS One. 2015;10(9):e0139097.

2. Batchelor HK, Marriott JF. Paediatric Pharmacokinetics: Key Considerations. British JournalofClinical Pharmacology. 2013;3(79):395404.

3. Lu Hong, Rosenbaum S. Developmental Pharmacokinetics in Pediatric Populations. J 
Pediatr Pharmacol Ther. 2014;19(4):262-76

4. Huang SS, Avery TR, Song Y, Elkins KR, Nguyen CC, Nutter SK, et al. Quantifying Interhospital Patient Sharing as a Mechanism for Infectious Disease Spread. NIH Public Access. 2010;11(31):1160-9.

5. Hanifah WH W, JKF L, BS Q. Comparison Of The Pattern Of Nosocomial Infection Between The Neonatal Intensive Care Units of Hospitals Kuala Terengganu And Universiti Sains Malaysia, Kelantan. Malaysian Journal of Medical Sciences. 2000;7(1):33-40.

6. Melekolkottab M, Shojaei L, Doomanlou M. Clinical Response and Outcome in Patients with Multidrug Resistant Gram-negative Infections. J Res Pharm Pract. 2017;1(6):44-51

7. Hadi U, Kuntaman, Qiptiyah M, Paraton. Case Report, Problem of Antibiotic Use And Antimicrobial Resistance In Indonesia: Are We Really Making Progress?. Indonesian Journal of Tropical and Infectious Disease. 2013;4(4):5-8

8. Xu Yanling, Gu Bing, Huang M, Liu H, Xu T, Xia W, Wang T. Epidemiology Of Carbapenem Resistant Enterobacteriaeceae (CRE) during 2000-2012 in Asia. J Thorac Dis. 2015;7(3):376-85.

9. He X, Xie M, Li S, Ye J, Peng Q Ma Q et al. Antimicrobial resistance in bacterial pathogens among hospitalized children with community acquired lower respiratory tract infections in Dongguan, China (2011- 2016). BMC Infect Dis. 2017;17(1):614.

10. Hadi U, Offra Duerink D, Lestari3 ES, Nagelkerke NJ, Keuter M, Huis In't Veld D, et al. Surveillance Of Healthcare-Associated Infection In Indonesian Hospitals. The Journal of Hospital Infection. 2006;62:219-29.

11. Veryanti P, Rianti A, Sugianti I. Evaluasi Penggunaan Antibiotik Pada Pasien Sepsis Neonatorum di Rumah Sakit Umum Pusat (RSUP) Fatmawati Jakarta Tahun 2016. Jakarta: Rakernas \& Pertemuan Ilmiah Tahunan Ikatan Apoteker Indonesia. 2017;134-8.

12. Bytyqi HQ, Hoxha R, Bahtiri E, Krasniqi V, Krasniqi S. Antibiotic Utilization in Pediatric Hospitalized
Patients - A Single Center Study. Macedonian Journal of Medical Sciences. 2017;5(2):256-60.

13. Permenkes RI. Peraturan Menteri Kesehatan RI Nomor 8 Tahun 2015 Tentang: Program Pengendalian Resistensi Antimikroba Di Rumah Sakit. Jakarta: Kementerian Kesehatan RI; 2015.

14. World Health Organization. Guidelines for ATC classification and DDD assignment 2019. Oslo, Norway: WHO Collaborating Centre for Drug Statistics Methodology; 2019.

15. Permenkes RI. Peraturan Menteri Kesehatan RI Nomor 2406 Tahun 2011 Tentang: Pedoman Umum Penggunaan Antibiotik. Jakarta: Menteri Kesehatan RI; 2011.

16. Muslim Z. Antibiotic Prescription To Pediatric In Hospital Bengkulu, Indonesia: ATC/DDD Index. Int J Pharm Pharm Sci. 2018;10(5):31-4.

17. Mahmudah F, Sumiwi SA, Hartini S. Study of the Use of Antibiotics with ATC/DDD System and DU 90\% in Digestive Surgery in Hospital in Bandung. Indones J Clin Pharm. 2016;5(4):293-8.

18. Herawati F, Pua Upa SM, Yulia R, Andrajati R. The Antibiotic Consumption At A Public Hospital In Indonesia. Asian J Pharm Clin Res. 2019;12(8):647.

19. Bell BG, Schellevis F, Stobberingh E, Goossens H, Pringle M.A systematic review and meta-analysis of the effects of antibiotic consumption on antibiotic resistance. BMC Infect Dis. 2014;14(1):13.

20. Naderi P, Shirani K, Soltani R, Khorvash F, Esfahani SSN. Meropenem Utilization Evaluation in a Referral Teaching Hospital in Iran. J Res Pharm Pract. 2018;7(2):83-7.

21. Catania VD, Boscarelli A, Lauriti G, Morini F, Zani A. Risk Factors for Surgical Site Infection in Neonates: A Systematic Review of the Literature and Meta-Analysis. Front Pediatr. 2019; 7:101.

22. Setiawan E, Wibowo Y, Setiadi AP, Nurpatria Y, Sosilya H, Wardhani DK, Costa MO, Aziz Abdul $\mathrm{MH}$, Roberts J. Implementasi Antimicrobioal Stewardship Program di Kawasan Asia: Sebuah Kajian Sitematis. Jurnal Farmasi Klinik Indonesia. 2019;2(8):141-56. 